D. Myszka, R. Haratym, K. Skalski ${ }^{1}$

Politechnika Warszawska, Wydział Inżynierii Produkcji, Instytut Technologii Materiałowych,

${ }^{1}$ Politechnika Warszawska, Wydział Inżynierii Produkcji, Instytut Mechaniki i Konstrukcji, ul. Narbutta 85, 02-524 Warszawa

\title{
CENA DOKŁADNOŚCI TYTANOWYCH ODLEWÓW ENDOPROTEZ
}

\begin{abstract}
STRESZCZENIE
$\mathrm{W}$ artykule przedstawione zostały zagadnienia związane $\mathrm{z}$ wpływem technologii wytwarzania odlewów precyzyjnych na dokładność wymiarową i jakość powierzchni endoprotez tytanowych. Przedstawiony został szczegółowo cykl otrzymywania odlewanych endoprotez obejmujący: obrazowanie kliniczne pacjenta poprzez tomografię komputerowa, modelowanie geometryczne - wytwarzanie modeli fizycznych metodą stereolitografii oraz wykonanie modeli woskowych oraz form ceramicznych i odlewów tytanowych. Cykl ten przedstawiono na przykładzie endoprotezy kości żuchwy. Wykonane badania obejmują ocenę dokładności wymiarowej oraz analizę makro- i mikrogeometrii powierzchni odlewów.
\end{abstract}

Stowa kluczowe: endoprotezy, precyzyjne odlewy tytanowe, doktadność

\section{WSTĘP}

Jedną z klasycznych metod wytwarzania wyrobów z tytanu i jego stopów są metody odlewania precyzyjnego. Ze względu jednak na znaczne trudności z utrzymaniem jakości odlewów na wysokim poziomie technologicznym prym w tej technologii wiodą najbardziej rozwinięte kraje świata. W Polsce odlewnie tytanu jest znane głównie małym przedsiębiorcom $\mathrm{w}$ szczególności wyrobów endoprotez stomatologicznych, $\mathrm{u}$ których popyt na te wyroby stale rośnie. Prowadzone są zatem badania nad poprawą jakości wytwarzanych wyrobów odlewanych zarówno pod względem morfologii ich powierzchni oraz wewnętrznej struktury. Równolegle brane pod uwagę jest również wytwarzanie w kraju tytanowych protez innych niż stomatologiczne, tj. do stawów człowieka (endoprotez).

Na Politechnice Warszawskiej na Wydziale Inżynierii Produkcji oraz w Instytucie Odlewnictwa w Krakowie rozwijane są ostatnio prace nad wytwarzaniem prototypów tytanowych endoprotez dedykowanych dla konkretnych pacjentów. Takie badania mają uzasadnienie $\mathrm{w}$ połączeniu wielu elementów składowych procesu wytwarzania odlewanej endoprotezy w jednym cykl produkcyjnym. Składają się na niego: tomografia komputerowa, modelowanie geometryczne, szybkie prototypowanie, wytwarzanie modeli woskowych i form ceramicznych oraz proces odlewania tytanu. Wiele z powierzchni zewnętrznych endoprotezy wytwarzanej tą technologią nie będzie 
podlegało obróbce skrawaniem, zatem precyzyjne określenie możliwości wpływu procesu odlewniczego na topografię jej powierzchni oraz warstwę wierzchnią ma swoje uzasadnienie. Szczególnie w przypadku kształtowania makro- i mikrogeometrii powierzchni endoprotezy w ściśle określony sposób, właściwy z medycznego punktu widzenia [1]. Wykonanie tego typu kształtów może nastręczać wiele trudności procesom obróbek ubytkowych lub technologiom inżynierii powierzchni, dlatego odlewanie stanowi niejednokrotnie rozwiązanie bardzo konkurencyjne, a czasem niezastąpione. Trudności w wytwarzaniu endoprotez polegają również na tym, że ich powstawanie wiąże się z produkcją jednostkową oraz z jak najszybszym dostarczeniem wszczepu przeznaczonego dla oczekującego pacjenta. Takie rozwiązania wiążą się zwykle ze znacznymi kosztami i długim czasem oczekiwania na sprowadzenie odpowiedniego elementu od właściwego producenta. Niezwykle przydatne w takich przypadkach stają się techniki szybkiego prototypowania, dzięki którym prototyp endoprotezy może powstać na bazie modelu geometrycznego zbudowanego na bazie tomografii komputerowej pacjenta. Takie rozwiązania stosowane są również w Polsce w pracach realizowanych przy współudziale Zakładu Konstrukcji Maszyn i Inżynierii Biomedycznej Politechniki Warszawskiej [2].

W celu określenia możliwości procesu wytwarzania odlewanej endoprotezy tytanowej i połączenia go z metodami szybkiego wytwarzania prototypu modelu fizycznego, wg schematu zaprezentowanego na rysunku 1, podjęto próbę wykonania kilku przykładowych endoprotez przy współudziale Zakładu Konstrukcji Maszyn i Inżynierii Biomedycznej oraz Zakładu Odlewnictwa Politechniki Warszawskiej i Instytutu Odlewnictwa z Krakowa.

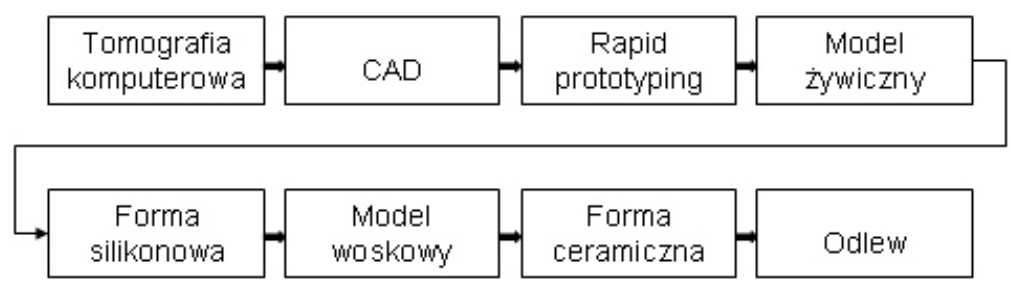

Rys.1. Schemat ścieżki technologiczno-konstrukcyjnej wykorzystanej do wytworzenia odlewu precyzyjnego tytanowej endoprotezy

\section{METODYKA BADAŃ}

Pracę zrealizowano dla trzech wyrobów: dwóch próbek o kształcie fragmentu endoprotezy koszyka stawu biodrowego oraz fragmentu endoprotezy stawu kolanowego (rys.2a,b - oznaczone w dalszej części artykułu jako: A i B), a także endoprotezy kości żuchwy (rys 2c-oznaczanej jako C).

Tytanowe odlewy A, B i C nie były wykonane w ten sam sposób. Jedynie procesy przygotowania form i odlewania przebiegały identycznie, dlatego poniżej wyodrębniono inny schemat przygotowania odlewu $\mathrm{C}$ - w tym przypadku zastosowano technikę przedstawioną na rysunku 1 


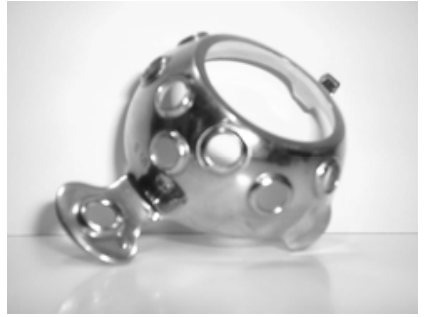

a)

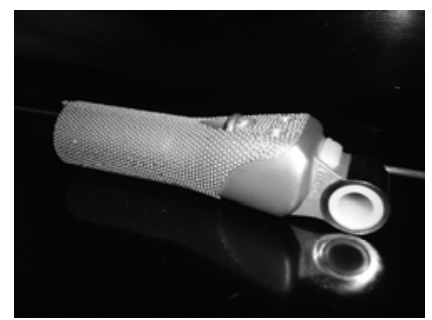

b)



c)

Rys.2. Endoprotezy: (A) koszyka stawu biodrowego, (B) stawu kolanowego, (C) żuchwy

Modele woskowe przygotowane były na bazie pierwowzorów modeli endoprotez rzeczywistych A i B. Na obu wybrano powierzchnie płaskie $i$ te, $z$ makronierównościami, jako powierzchnie bazowe do dalszych badań. Modele zostały przygotowane $\mathrm{z}$ czerwonego wosku jubilerskiego firmy Castaldo zalewanego do form silikonowych $\mathrm{z}$ temperatury $86^{\circ} \mathrm{C}$. Na przygotowanych zestawach modelowych nakładano warstwowe formy ceramiczne, których pierwsza warstwa była wykonywana na bazie specjalnej mieszanki ceramicznej złożonej $\mathrm{z}$ mączki $\mathrm{ZrO}_{2}$ ze spoiwem Titanbinder $\left(\mathrm{ZrO}_{2} /\right.$ Titanbinder). Pozostałe warstwy form ceramicznych wykonywane były na bazie spoiwa Ekosil i piasku kwarcowego o ziarnistości od 0,1 do $1 \mathrm{~mm}$. Gotowe formy następnie opróżniano $\mathrm{z}$ wosku w autoklawie, a następnie wyżarzano przez 2 godziny $\mathrm{w}$ temperaturze $900^{\circ} \mathrm{C}$. Odlewy z czystego tytanu wykonane były w piecu próżniowym odśrodkowym Titancast 700, a po ochłodzeniu na powietrzu oczyszczane za pomoca piaskowania.

Wykonanie odlewu $\mathrm{C}$ rozpoczęto od modelowania geometrycznego żuchwy na podstawie zdjęć tomograficznych wykonanych w Wojskowym Instytucie Medycznym w Warszawie. Dostarczone skany tomograficzne pacjenta były wykonane w płaszczyźnie poziomej co $0,5 \mathrm{~mm}$ (rys.3a). Do przetworzenia zdjęć tomograficznych w wersję zwizualizowaną (rys.3b) wykorzystany został format DICOM, natomiast do utworzenia 3D modelu geometrycznego (rys.3c), belgijski program Mimics 8.11. Wygenerowany model został zapisany z rozszerzeniem .stl, a następnie przetworzony przez główny program Maestro sterujący procesem technologicznym RP-SLA (rapid prototyping metodą stereolitografii). Ta właśnie technika została wykorzystana na Politechnice Warszawskiej do wytworzenia modelu fizycznego [3]. Model fizyczny został wykonywany z żywicy epoksydowej SL 5170, która była utwardzana wiązką światła ultrafioletowego. Na podstawie modelu żywicznego została wykonana forma $\mathrm{z}$ żywicy silikonowej ESSIL 291 Resin. Po zakończeniu tego procesu forma została rozcięta $\mathrm{W}$ celu usunięcia modelu żywicznego (rys.4a). W matrycy silikonowej został wykonany model (rys.4b) $\mathrm{z}$ czerwonego wosku jubilerskiego firmy Castaldo zalewanego do form silikonowych w temperaturze $86^{\circ} \mathrm{C}$. Proces wykonania odlewu $\mathrm{C}$ był identyczny jak dla odlewów A i B.

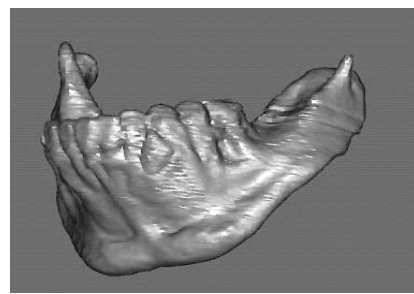

a)

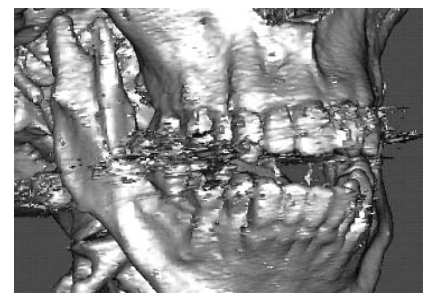

b)

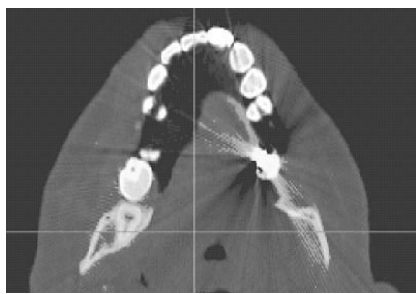

c)

Rys.3. Modelowanie kości żuchwy pacjenta: (a) przykładowy obraz tomograficzny, (b i c) modele geometryczne czaszki i kości żuchwy 
a)

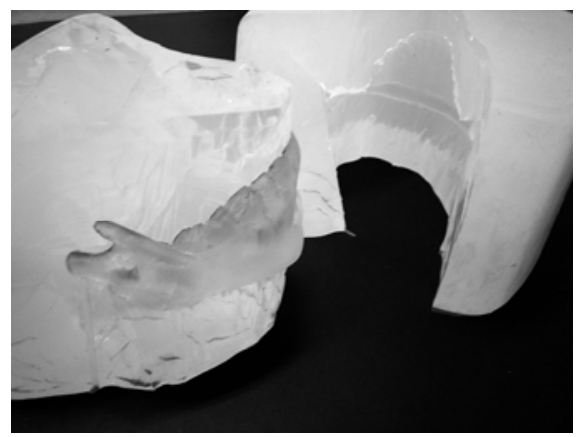

b)



Rys.4. Modele: (a) żywiczny w formie silikonowej i (b) woskowy

Wszystkie modele oraz odlewy A, B i C zostały ocenione pod względem jakości powierzchni i jej chropowatości za pomocą mikroskopu stereoskopowego OLYMPUS SZX9 oraz profilometru S3P firmy ZEISS. Ponad to, na endoprotezie kości żuchwy, przeprowadzono badania odwzorowania kształtu i dokładności wymiarowej modeli fizycznych: żywicznego i woskowego endoprotezy oraz odlewu tytanowego.

\section{WYNIKI BADAŃ I DYSKUSJA}

Wyniki pomiarów chropowatości dla powierzchni modeli i odlewów, które przedstawiono tabeli 1, wskazują na dokładne odwzorowanie płaskich powierzchni woskowych na powierzchnie odlewane $\mathrm{z}$ tytanu. $\mathrm{Z}$ obserwacji makroskopowych (rys.5a,b) wynika jednak, że oprócz właściwego odzwierciedlenia kształtu modelu woskowego $\mathrm{w}$ odlewie np. w postaci sferycznych makronierówności, pozostałości drobnych zabrudzeń powierzchni modelu są również przenoszone na odlew. Dlatego niezwykle ważne jest właściwe przygotowanie modelu endoprotezy $\mathrm{w}$ celu oczyszczenia powierzchni z niepożądanych drobin woskowych.

Tabela 1. Wyniki pomiarów chropowatości powierzchni modeli i odlewów tytanowych

\begin{tabular}{|c|c|c|}
\hline \multirow{2}{*}{ Rodzaj endoprotezy } & \multicolumn{2}{|c|}{ Badana powierzchnia } \\
\hline & Model woskowy & Odlew tytanowy \\
\hline A & 1,36 & 3,02 \\
\hline B & 1,63 & 3,23 \\
\hline $\mathrm{C}$ & 0,97 & 2,37 \\
\hline
\end{tabular}

a)

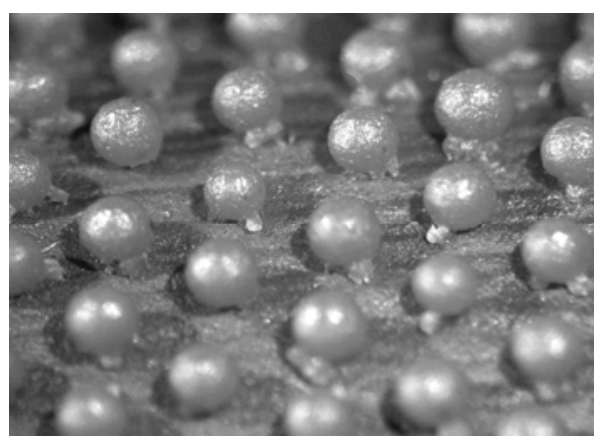

b)

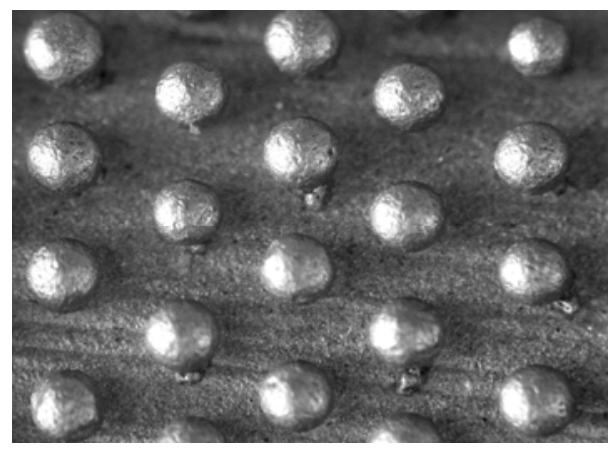

Rys.5. Fragment powierzchni modelu woskowego i odlewu B (odpow. a,b). Pow. x50 
$\mathrm{Na}$ zdjęciu z rysunku 6a widoczne jest dokładne odwzorowanie w skali makro- i mikroskopowej powierzchni modelu żywicznego na gotowy odlew tytanowy. Charakterystyczne jest przeniesienie na powierzchnię odlewu „schodkowych” efektów procesu stereolitografii (rys.6a). Taka powierzchnia wynika z technologii otrzymywania modelu stereolitograficznego, gdzie żywica utwardzana jest w kolejnych, przyrostowych warstwach co $0,1 \mathrm{~mm}$. Efekty te można usunąć z modelu poprzez wygładzenie powierzchni.

a)



b)



Rys.6. (a) Fragment powierzchni odlewu C i (b) model C z oznaczeniem wymiarów kontrolnych

Pomiary wielkości geometrycznych modeli zostały wykonane na modelu żywicznym, woskowym oraz na gotowym odlewie z tytanu dla charakterystycznych wymiarów określanych jako kontrolne (rys.6b). Każda seria pomiarowa składała się z pięciu pomiarów wymiarów długości. Po wyznaczeniu wartości średniej wymiaru, jako średniej arytmetycznej, określony został odpowiedni wymiar wnęki formy silikonowej, a następnie względna wielkość skurczu modelu woskowego. Z badań materiałów na modele wytapiane ustalono, że skurcz mieszanek modelowych (przy chłodzeniu naturalnym) wynosi od 0,9 do $1,1 \%$. Dla takiego typu mieszanek należy się spodziewać odchyłki wymiarowej modeli od 0,2 do $0,25 \%$ (skurcz swobodny).

Podstawowym zagadnieniem przy pomiarach złożonych elementów, takich jak np. endoproteza kości żuchwy, jest stałość baz pomiarowych podczas pomiaru zarówno modeli jak i odlewu tytanowego. Pomimo stosowania przyrządu pomiarowego $\mathrm{z}$ podziałką elementarną $0,01 \mathrm{~mm}$ i niedokładności maksymalnej $\pm 0,01 \mathrm{~mm}$, zakres niedokładności pomiarów dla poszczególnych wymiarów z rysunku 12 wynosiła dla $\mathrm{G}$ i G1 od $\Delta=0,16 \mathrm{~mm}$ do $\Delta=0,20 \mathrm{~mm}$ dla modelu żywicznego i woskowego oraz 0,05 do $0,10 \mathrm{~mm}$ dla odlewu. W przypadku wymiaru A ze skurczem mieszanym zakres ten wynosi: od $\Delta=0,16 \mathrm{~mm}$ do $\Delta=0,50 \mathrm{~mm}$ dla modeli oraz $\Delta=0,12 \mathrm{~mm}$ dla odlewu. Dla wymiaru D ze skurczem swobodnym otrzymano odpowiednio: $\Delta=0,10 \mathrm{~mm}$ dla modelu żywicznego i $\Delta=0,37 \mathrm{~mm}$ dla modelu woskowego oraz $\Delta=0,11 \mathrm{~mm}$ dla odlewu. $\mathrm{Na}$ podstawie wcześniejszych badań ustalono, że wartość parametru L - M [\%] może służyć do ustalenia odchyłki wymiarowej odlewu. Przy takiej ocenie populacja badana może się składać $\mathrm{z}$ dwóch próbek odpowiednio dla wymiarów ze skurczem swobodnym, mieszanym i hamowanym (wymiary A i D) oraz dla wymiarów grubości (wymiary G i G1). Ocenę parametru L - M [\%] przedstawiono w tabeli 2.

Korzystając z ogólnego wzoru na dokładność wymiarową (1) otrzymano dla wymiarów $\mathrm{G}$ i G1: odchyłkę wymiarową $\Delta \mathrm{L}=1,87 \%$, w stosunku do wymiaru nominalnego. Natomiast dla wymiaru A ze skurczem mieszanym: odchyłkę $\Delta \mathrm{L}=0,92 \%$, w stosunku do wymiaru nominalnego zaś dla wymiaru $\mathrm{D}$ ze skurczem swobodnym: $\Delta \mathrm{L}=0,90 \%, \mathrm{w}$ stosunku do wymiaru nominalnego. 
Tabela 2. Ocena parametru $(L-M)$ dla wymiarów $G, G 1, A$ i $D$

\begin{tabular}{|c|c|c|c|c|}
\hline \multirow{2}{*}{$\begin{array}{c}\text { Nr } \\
\text { pomiaru }\end{array}$} & \multicolumn{4}{|c|}{ Wymiary } \\
\cline { 2 - 5 } & $\mathrm{G}$ & $\mathrm{G} 1$ & $\begin{array}{c}\mathrm{A} \\
\text { (skurcz mieszany) }\end{array}$ & $\begin{array}{c}\mathrm{D} \\
\text { (skurcz swobodny) }\end{array}$ \\
\cline { 2 - 5 } & $\mathrm{L}-\mathrm{M}[\%]$ & $\mathrm{L}-\mathrm{M}[\%]$ & $\mathrm{L}-\mathrm{M}[\%]$ & $\mathrm{L}-\mathrm{M}[\%]$ \\
\hline 1 & 0,9 & 1,5 & 0,91 & 0,95 \\
\hline 2 & 1,16 & 1,7 & 0,79 & 1,09 \\
\hline 3 & 0,9 & 2,0 & 0,95 & 0,75 \\
\hline 4 & 0,2 & 2,3 & 0,93 & 0,72 \\
\hline Średnia arytmetyczna & 0,8 & 1,88 & 0,90 & 0,88 \\
\hline
\end{tabular}

$\Delta \mathrm{L}=\Delta \mathrm{M}^{2}+\Delta(\mathrm{L}-\mathrm{M})^{2}$

gdzie: L - wymiar odlewu; M - wymiar modelu; $\Delta \mathrm{L}$ - odchyłka wymiarowa dla odlewu; $\Delta \mathrm{M}$ - odchyłka wymiarowa dla modelu

WNIOSKI

Z uzyskanych wyników oraz przeprowadzonych analiz nasuwa się wniosek, iż odwzorowanie złożonej geometrii powierzchni modelu endoprotezy jest możliwe na drodze odlewania precyzyjnego tytanu, w której wykorzystano procesy modelowania komputerowego i szybkiego prototypowania. W projektowaniu powierzchni odlewu tytanowej endoprotezy należy uwzględnić szereg czynników technologicznych oraz materiałowych, np. technologię wykonywania modelu fizycznego powstającego na drodze stereolitografii, technologię wykonywania modeli woskowych lub skurcz wosku czy metalu, które mają także znaczny wpływ na jego dokładność wymiarową.

\section{LITERATURA}

1. Wierzchoń T., Czarnowska E., Krupa D.: Inżynieria powierzchni w wytwarzaniu biomateriałów tytanowych, Oficyna Wydawnicza PW, Warszawa 2004.

2. www.imik.wip.pw.edu.pl

3. Myszka D., Wróblewski G., Karwiński A.: Zastosowanie szybkiego prototypowania do wytwarzania odlewanych endoprotez tytanowych, Materiały na XXXI Sympozjum Naukowe Zakładu Odlewnictwa PW, Warszawa, 2006, 19-26. 